УДК $577.1+574.2$

\title{
СОСТАВ ЛИПИДОВ ЛИСТЬЕВ НЕКОТОРЫХ ПРЕДСТАВИТЕЛЕЙ POL YРОDIOРНYTA НА ПРИПОЛЯРНОМ УРАЛЕ
}

\author{
(ㄷ) О.А. Розенцвет ${ }^{I}$, Е.С. Богданова ${ }^{l *}$, Т.К. Головко ${ }^{2}$, И.Г. Захожий ${ }^{2}$ \\ ${ }^{1}$ Институт экологии Волжского бассейна РАН, ул. Комзина, 10, Тольятти, \\ 445003 (Россия), e-mail: cornales@mail.ru \\ ${ }^{2}$ Институт биологии Коми научного центра УрО РАН, \\ ул. Коммунистическая, 28, Сыктывкар, 167982 (Россия)
}

\begin{abstract}
Исследовали состав липидов и жирных кислот листьев шести видов - представителей двух классов Polypodiophyta, произрастающих на Приполярном Урале. У растений класса Polypodiopsida превалировали гликолипиды (58-66\% суммы липидов), на долю липидов бетаинового типа приходилось 0,1-1,4\%. У представителя Ophioglossopsida доминировали фосфолипиды (43\%), а бетаиновые липиды отсутствовали. Основную группу жирных кислот составляли кислоты с длиной цепи 16-24 атомов углерода. Установлено, что содержание и соотношение основных групп липидов больше зависело от таксономической и ботанико-географической принадлежности, но слабо связано с экологической группой и ценотической приуроченностью.

Ключевые слова: жирные кислоты, запасные липиды, мембранные липиды, Ophioglossopsida, Polypodiopsida.
\end{abstract}

\section{Введение}

Среди современных растений папоротники, или птеридофиты, являются одной из древнейших и наиболее жизнеспособных групп. От общего количества сосудистых растений папоротники составляют от 2 до 5\% и играют важную экологическую роль во многих лесообразующих растительных сообществах [1, 2]. Птеридофиты являются тайнобрачными растениями, для полного завершения жизненного цикла им необходима капельно-жидкая среда, поэтому наибольшее их разнообразие наблюдается во влажных тропических и субтропических лесах. Однако они приспособились к широкому разнообразию условий обитания [3, 4]. Многие виды папоротникообразных растений встречаются в областях с холодным субарктическим и арктическим климатом, а также с аридным континентальным климатом, вблизи границ полярного пояса и в высокоширотных арктических районах, в каменистых лишайниковых тундрах [5, 6]. Уникальность таких растений заключается в том, что их метаболизм адаптирован к суровым климатическим условиям, что позволяет папоротникам успешно расти и развиваться даже в самых экстремальных условиях среды. В связи с этим папоротники представляют огромный интерес в изучении стратегии выживания растительных организмов в различных природно-климатических условиях [7].

Важную роль в процессах адаптации играют липиды [8]. За счет модификаций мембранных липидов и углеводородных радикалов их жирных кислот (ЖК) происходит регулирование состояния внутриклеточ-

Розенивет Ольга Анатольевна - доктор биологических наук, тел.: (8482) 48-96-09, e-mail: olgarozen@ pochta.ru Богданова Елена Сергеевна - младший научный сотрудник, тел.: (8482) 48-96-09,

e-mail: cornales@mail.ru

Головко Тамара Константиновна - доктор биологических наук, тел. (8212) 24-11-19, e-mail: golovko@ib.komisc.ru

Захожий Илья Григорьевич - старший научный сотрудник, кандидат биологических наук, тел.: (8212) 24-11-19, e-mail: zakhozhiy@ib.komisc.ru ной среды, поддержание структурных и функциональных свойств как макромолекул, так и всего растительного организма [9]. В ранних наших работах было показано, что мембранные липиды в листьях папоротников, произрастающих в разных экологических условиях в пределах одного географического района, претерпевают качественные и количественные изменения в зависимости от видовых особенно-

\footnotetext{
* Автор, с которым следует вести переписку.
} 
стей, условий обитания, стадии роста. Например, у папоротников умеренной зоны Dryopteris carthusiana, D. filix-mas; Matteuccia struthipteris и Pteridium aquilinum выявлено увеличение содержания фосфатидилглицерола в составе полярных фосфолипидов (ФЛ) листьев по мере их роста. Обнаружены также существенное изменение содержания бетаинового липида 1,2-диацилглицеро-3-O-4'-(N,N,N-триметил)гомосерина (ДГТС) в листьях в течение вегетационного периода $[10,11]$. Для большинства видов вечнозеленых тропических папоротников такие изменения не выявлены [12]. Сведения о липидном составе папоротников, обитающих в высоких широтах, единичны [13], что затрудняет получение более полной картины о функциональных и биохимических адаптациях высших споровых растений к суровым климатическим условиям. Ранее нами было установлено, что папоротники Приполярного Урала не отличались существенно от большинства травянистых цветковых растений данного региона по накоплению фотосинтетических пигментов и дыхательной активности листьев [14,15].

Цель настоящей работы - исследование состава липидов у представителей двух классов папоротниковидных - Ophioglossopsida и Polypodiopsida в условиях Приполярного Урала.

\section{Экспериментальная часть}

Район исследований расположен на Приполярном Урале $\left(65^{\circ}\right.$ с.ш., $61^{\circ}$ в.д.) в северной части национального парка «Югыд Ва» в подзоне крайне-северной тайги. Основной тип растительности представлен горными лесами, которые распространены до высоты примерно 500 м над ур. моря [16, 17]. Горно-лесной пояс начинается с полосы еловых и елово-березовых лесов. С подъемом в горы они замещаются лиственничными лесами, затем лиственничными редколесьями, а еще выше сменяются ерниковыми и моховолишайниковыми горными тундрами. Основу флоры района исследований составляют покрытосеменные, видовое разнообразие голосеменных невелико, но именно они определяют облик ландшафтов. В горах и предгорьях заметно возрастает ценотическая роль сосудистых споровых растений (плауны, хвощи, папоротники), в общей сложности они составляют около $6 \%$ всей флоры, насчитывающей в настоящее время около 370 видов.

Климат региона суровый, с длительной холодной зимой и коротким прохладным летом; активный вегетационный период длится примерно 60 дней. Среднегодовая температура воздуха составляет $-4,8^{\circ} \mathrm{C}$, средняя температура самого теплого месяца июля немного выше $+12{ }^{\circ} \mathrm{C}$, а наиболее холодного месяца января $-21^{\circ} \mathrm{C}$, за год выпадает примерно 900 мм осадков. В период активной вегетации возможны значительные суточные перепады температуры, достаточно часто отмечаются ночные заморозки [18].

Растительный материал. Исследовано шесть видов папоротников, что составляет $26 \%$ видового разнообразия Polypodiophyta в национальном парке «Югыд-Ва». Из них пять видов представляют класс Polypodiopsida: Woodsia glabella R. Br., Dryopteris expansa (C. Presl) Fraser-Jenkin set Jermy, Athyrium distentifolium Tausch ex Opiz, Cystopteris dickieana R. Sim., Gymnocarpium dryopteris (L.) Newman; один вид Bothychium lunaria (L.) - класc Ophioglossopsida (табл. 1). Woodsia glabella входит в список видов сосудистых растений национального парка «Югыд-Ва», охраняемых в Республике Коми.

Образцы листьев отбирали в июле 2010 г., произрастающих в предгорных и горных лесах, на лугах и скалах в бассейне верхнего течения р. Кожим.

Общуие аналитические методы. Для биохимического анализа использовали листья из 10-20 растений, составляли три независимых биологических пробы (2-4 г сырой массы). Деферментацию образцов проводили кипящим изопропанолом и до анализа хранили в темном холодном месте.

Липиды экстрагировали трижды смесью хлороформа и метанола (1:2, v/v) с одновременным механическим разрушением тканей при помощи стеклянных шариков $[19,20]$. Объединенные экстракты отмывали от нелипидных примесей, растворитель отгоняли на роторно-вакуумном испарителе. Количество общих липидов определяли гравиметрически после полного удаления растворителей.

Разделение ФЛ проводили методом двумерной тонкослойной хроматографии (ТСХ) на стеклянных пластинках 6×6 см с закрепленным слоем силикагеля с использованием систем растворителей: первое направление: хлороформ - метанол - бензол - аммиак (130:60:20:12); второе направление: хлороформ метанол - бензол - ацетон - уксусная кислота (140: $60: 20: 10: 8)$. Проявляли ФЛ 10\%-й $\mathrm{H}_{2} \mathrm{SO}_{4}$ в метаноле с последующим нагреванием при температуре $180{ }^{\circ} \mathrm{C}$ в течение 15 мин. Количество ФЛ определяли по содержанию неорганического фосфора [20, 21]. 
Гликолипиды (ГЛ) разделяли методом одномерной ТСХ на пластинках $10 \times 10$ см с использованием системы растворителей: ацетон - бензол - вода (91:30:8 по объему). Проявляли ГЛ 5\%-м раствором $12 \mathrm{MoO}_{3} \times \mathrm{H}_{3} \mathrm{PO}_{4}$ в метаноле с последующим нагреванием при температуре $150{ }^{\circ} \mathrm{C}$ в течение 10 мин. Липиды идентифицировали при помощи стандартов и реагентов на отдельные функциональные группы Sigma, Larodan (Швеция) [20]. Количественный анализ проводили на денситометре «Денскан».

Содержание бетаинового липида, или ДГТС, измеряли спектрофотометрически, как описано в работе [22].

Для анализа ЖК использовали их метиловые эфиры, полученные кипячением с 5\%-й $\mathrm{HCl}$ в метаноле. Полученные эфиры анализировали на хроматографе «Хроматэк Кристалл 5000.1» (Россия) с использованием капиллярной колонки длиной 105 м и диаметром 0,25 мм RESTEK (США). Температура колонки $180{ }^{\circ} \mathrm{C}$, испарителя и детектора $-260{ }^{\circ} \mathrm{C}$. Скорость тока газа-носителя (гелий) 2 мл/мин.

Статистическую обработку результатов проводили с помощью программ Statistica 6.0 for Windows и Microsoft Excel 2007. Значения в таблицах и рисунках представляют средние арифметические из трех независимых биологических повторностей и их стандартные ошибки. Достоверность различий оценивали на основании t-критерия Стьюдента при доверительном интервале $\mathrm{P} \leq 0,05$.

\section{Обсуждение результатов}

Географический анализ флоры показал, что все исследованные виды папоротников обитают на одной голарктической долготе и пяти широтах: арктоальпийской (W. glabella), гипоаркто-монтанной ( $C$. dickieana), бореально-монтанной (D. expansa, A. distentifolium) бореальной (G. dryopteris) и плюризональной (B. lunaria) (табл. 1). По экологическому режиму, обусловленному увлажнением, все виды, за исключением A. distentifolium, являются мезофитами. Растения охватывают различные типы фитоценозов - от луговых и лесных сообществ до высокогорных и скальных.

В таблице 2 приведены данные о содержании СЛ в листьях папоротников. Для сравнения включены данные о содержании СЛ (и далее других липидов) в листьях проанализированных нами ранее W. glabella и G. dryopteris, собранных на территории Южного Тимана [13]. У представителей Рolypodiopsida coдержание липидов варьировало значительно. При этом в листьях W. glabella и G. dryopteris, собранных на Приполярном Урале и Южном Тимане, количество СЛ было примерно одинаковым. У единственного представителя Ophioglossopsida содержание СЛ в листьях было наименьшим.

Состав СЛ исследованных видов был типичным для этой группы сосудистых растений (табл. 2). Химическое строение, локализация внутри клетки и функциональное значение ГЛ, ФЛ, ДГТС и НЛ различны [24]. С точки зрения систематики наибольшие отличия в соотношении этих групп липидов были выявлены для B. lunaria (Ophioglossopsida). В листьях B. lunaria содержание ГЛ было ниже, а ФЛ - выше, тогда как у других видов - наоборот. Известно, что ФЛ являются основными структурными липидами внехлоропластных мембран клеток, а ГЛ характерны для мембран хлоропластов. В сформировавшихся фотосинтезирующих органах высших растений отношение между этими классами липидов обычно составляет 60 : 40. Следует также отметить сравнительно высокое содержание НЛ и отсутствие ДГТС в листьях B. lunaria. У представителей Polypodiopsida ГЛ составляли большую часть СЛ, а содержание ФЛ было в 1,5-3 раза меньше, чем ГЛ. Состав НЛ, как правило, более вариабелен и может существенно меняться в зависимости от условий среды, возраста, таксономической принадлежности [25]. В листьях исследованных нами видов на НЛ приходилось от 5 (D. expansa) до 15\% (C. dickieana) СЛ.

Следует отметить влияние фактора географической принадлежности вида на соотношение основных групп липидов. Папоротники Polypodiopsida, относящиеся к бореально-монтанному типу распространения (D. expansa и A. distentifolium), характеризовались более высоким, в 1,5 раза, содержанием ФЛ по сравнению с гипоаркто-монтанным (C. dickieana) и бореальным видом (G. dryopteris).

Липиды бетаинового типа представляют особую группу полярных глицеролипидов. Листья скальных растений W. glabella, C. dickieana, A. distentifolium содержали почти на порядок больше ДГТС по сравнению с лесными и луговыми папоротниками. Однако в целом содержание ДГТС в листьях папоротников, произрастающих на Приполярном Урале, было намного ниже, чем у тропических видов папоротников. Ранее нами было обнаружено, что в условиях умеренной зоны листья папоротников D. carthusiana, D. filixmas; M. struthipteris и P. aquilinum в середине вегетационного периода содержали существенно меньше ДГТС, чем в начале и конце вегетации [10]. На Приполярном Урале образцы листьев папоротников были отобраны в июле, пробы были представлены в основном сформировавшимися функционально зрелыми 
листьями. Скорее всего, это и явилось причиной низкого содержания в них бетаинового липида ДГТС. Возможно также, что данный тип липидов малозначим для состояния клеточных мембран листьев папоротников в условиях Приполярного Урала.

Таблица 1. Классификация по систематическому, широтно-долготному и экологическому положению исследованных папоротников [23]

\begin{tabular}{|c|c|c|c|}
\hline $\begin{array}{l}\text { Систематическое поло- } \\
\text { жение }\end{array}$ & Долготный и широтный элементы & $\begin{array}{l}\text { Экологическая группа } \\
\text { к фактору увлажнения }\end{array}$ & $\begin{array}{c}\text { Ценотическая приуро- } \\
\text { ченность }\end{array}$ \\
\hline Ophioglossopsida & & & \\
\hline Ophioglossaceae & Голартический-плюризональный & Мезофит & Луговой \\
\hline Bothychium lunaria & & & \\
\hline Polypodiopsida & & & \\
\hline Athyrioidaceae & & & \\
\hline Athyrium distentifolium & Голартический бореально-монтанный & Психрофит & Высокогорный \\
\hline Cystopteris dickieana & Голарктический гипоаркто-монтанный & Мезофит & Скальный \\
\hline Gymnocarpium dryopteris & Голарктический бореальный & Мезофит & Лесной \\
\hline $\begin{array}{l}\text { Dryopteridoideae } \\
\text { Dryopteris expansa }\end{array}$ & Голартический бореально-монтанный & Мезофит & Лесной \\
\hline $\begin{array}{l}\text { Woodsiaceae } \\
\text { Woodsia glabella }\end{array}$ & Голартический-арктоальпийский & Мезофит & Скальный \\
\hline
\end{tabular}

Таблица 2. Суммарные липиды и соотношение разных классов липидов в листьях представителей Ophioglossopsida и Polypodiopsida

\begin{tabular}{|c|c|c|c|c|c|}
\hline \multirow{2}{*}{$\begin{array}{c}\text { Виды } \\
\text { папоротников }\end{array}$} & \multirow{2}{*}{$\begin{array}{c}\text { Суммарные липиды, } \\
\text { мг/г сырой массы }\end{array}$} & \multicolumn{4}{|c|}{ Содержание липидов, процент от суммы } \\
\hline & & ФЛ & ГЛ & НЛ & ДГТС \\
\hline B. lunaria (I) & $16,5 \pm 0,7$ & $42,6 \pm 1,6$ & $31,5 \pm 0,9$ & $26,0 \pm 0,0$ & - \\
\hline A. distentifolium (II) & $19,9 \pm 0,5$ & $31,1 \pm 0,9$ & $57,9 \pm 0,2$ & $10,0 \pm 1,0$ & $1,1 \pm 0,3$ \\
\hline C. dickieana (III) & $19,5 \pm 1,2$ & $19,1 \pm 1,1$ & $64,5 \pm 1,1$ & $15,1 \pm 0,3$ & $1,4 \pm 0,2$ \\
\hline G. dryopteris (IV) & $29,9 \pm 1,8$ & $18,8 \pm 0,7$ & $65,9 \pm 3,5$ & $12,1 \pm 1,3$ & $0,3 \pm 0,0$ \\
\hline G. dryopteris* (V) & $25,1 \pm 5,7$ & $19,0 \pm 0,4$ & $66,4 \pm 1,0$ & $14,3 \pm 1,0$ & $0,3 \pm 0,4$ \\
\hline D. expansa (VI) & $19,5 \pm 0,3$ & $33,6 \pm 4,6$ & $61,3 \pm 3,9$ & $5,1 \pm 0,7$ & $0,1 \pm 0,0$ \\
\hline W. glabella (VII) & $24,0 \pm 0,0$ & $21,2 \pm 1,0$ & $64,6 \pm 4,8$ & $13,6 \pm 3,8$ & $0,6 \pm 0,0$ \\
\hline W. glabella* (VIII) & $28,4 \pm 0,2$ & $26,2 \pm 2,4$ & $58,8 \pm 3,0$ & $14,0 \pm 2,8$ & $1,0 \pm 0,2$ \\
\hline
\end{tabular}

Примечание: * растения, собранные на Южном Тимане [13].

Анализ полученных результатов показывает, что различия в накоплении СЛ и соотношении основных групп липидов в большей степени зависели от таксономической и ботанико-географической принадлежности и меньше связаны с экологической группой и ценотической приуроченностью.

Гликолипиды представлены моногалактозилдиацилглицерином (МГДГ), дигалактозилдиацилглицерином (ДГДГ) и сульфохиновозилдиацилглицерином (СХДГ). Они являются важнейшими структурными элементами фотосинтетического аппарата - хлоропластных мембран и во многом определяют эффективность его функционирования [26-29]. Как видно на рисунке 1, в листьях всех исследованных нами видов папоротников превалировал МГДГ, на его долю приходилось в среднем 55\% всех ГЛ. Содержание ДГДГ варьировало в пределах 28-45\%, при этом наибольшее количество ДГДГ отмечено в листьях B. lunaria. Содержание сульфолипидов в листьях папоротников Polypodiopsida не превышало 20\%, а в листьях B. lunaria данный тип липидов был обнаружен в следовых количествах. В листьях растений W. glabella и G. dryopteris, обитающих на Южном Тимане, количество сульфолипидов составляло 6-7\%, что в 2,5 раза ниже величин, зарегистрированных у тех же видов на Приполярном Урале.

Фосфолипиды являются основными структурами плазматической мембраны, отделяющей клетку от внешней среды, и внутренних мембран, разделяющих клетку на отдельные компартменты [30]. Среди ФЛ листьев папоротников нами были идентифицированы фосфатилихолин (ФХ), фосфатидилэтаниламин (ФЭ), фосфатидилинозит (ФИ), фосфатидилглицерол (ФГ) и фосфатидная кислота (ФК). У всех видов растений преобладал ФХ, на его долю приходилось 30-50\% суммы ФЛ (рис. 2). По количеству за ним следуют ФЭ и ФГ. Следует отметить, что у растений W. glabella и G. dryopteris на Приполярном Урале уровень ФГ в 1,5 раза выше по сравнению с теми же видами на Южном Тимане. Увеличение концентрации ФГ может быть связано с необходимостью стабилизации комплексов фотосистем [31]. В составе ФЛ были идентифицированы и минорные компоненты фосфатидилсерин и дифосфатилидглицерол, их содержание не превышало 4\% суммы ФЛ. 


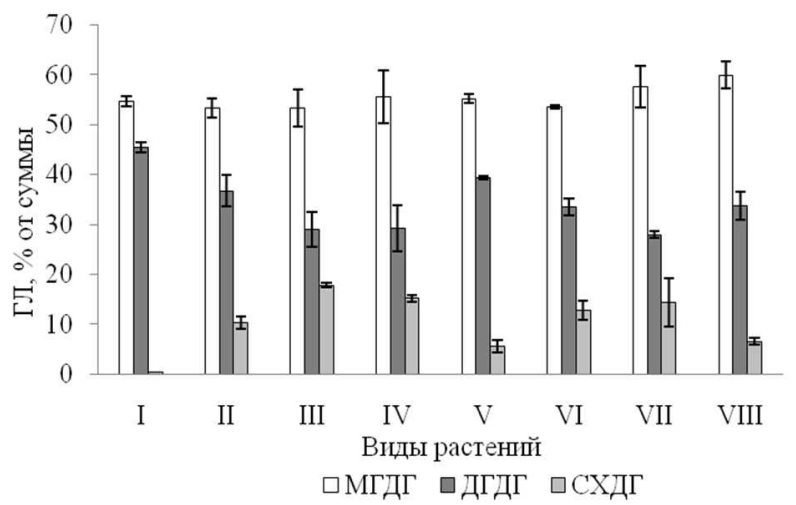

Рис. 1. Состав гликолипидов в листьях представителей Ophioglossopsida и Polypodiopsida: I - B. lunaria, II - A. distentifolium, III - C. dickieana, IV - G. dryopteris, V - G. dryopteris (Южный

Тиман), VI - D. expansa, VII - W. glabella, VIII - W. glabella (Южный Тиман)

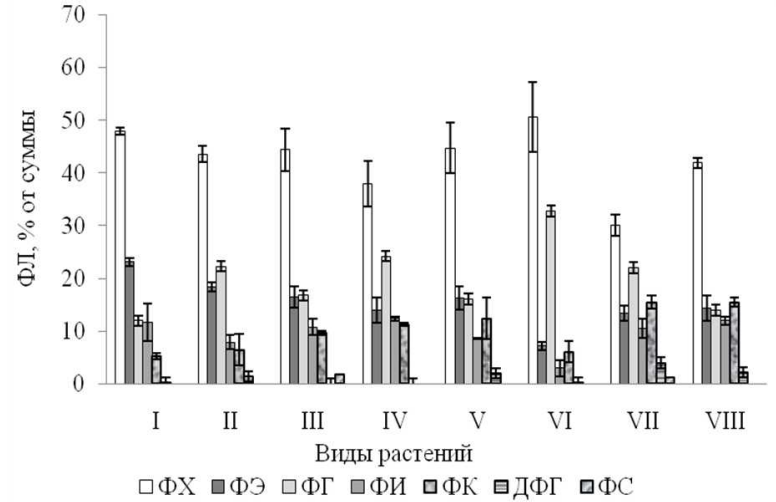

Рис. 2. Состав фосфолипидов в листьях представителей Ophioglossopsida и Polypodiopsida: I - B. lunaria, II - A. distentifolium, III - C. dickieana, IV - G. dryopteris, V - G. dryopteris (Южный Тиман), VI - D. expansa, VII - W. glabella, VIII - W. glabella (Южный Тиман)

Полученные данные позволяют заключить, что выявленные отличия в составе индивидуальных ГЛ и ФЛ определялись видовыми особенностями и условиями обитания растений в разных географических регионах.

Функциональные свойства липидов в сильной степени определяются составом их ЖК. Кроме обеспечения целостности мембран и оптимального уровня ненасыщенности, ЖК обусловливают включение и диффузное перемещение мембранных компонентов, активность мембраносвязанных ферментов, проницаемость, транспортные свойства [9]. Основную группу ЖК в исследованных папоротниках составляли кислоты с длиной цепи 16-24 атомов углерода (табл. 3). У всех видов среди насыщенных ЖК (НЖК) количественно преобладала пальмитиновая кислота (16:0), при этом максимальное ее содержание отмечено у $G$. dryopteris (30,4\%-34,7\%), а минимальное - у W. glabella $(13,5 \%)$, собранной на Южном Тимане. Среди ненасыщенных ЖК (ННЖК) доминировали $\alpha$-линоленовая (18:3n3), олеиновая (18:1n9c), линолевая (18:2n6c) кислоты. Содержание данных кислот варьировало в зависимости от вида и условий обитания. Например, в листьях папоротника B. lunaria преобладала 18:1n9c, а в листьях растений W. glabella, произрастающих в условиях Южного Тимана, отмечалось более высокое содержание 18:1n9с и 18:2n6c, чем в растениях Приполярного Урала.

Известно, что именно биосинтез диеновых и триеновых кислот обеспечивает устойчивость растений к низким температурам [32-34]. В целом состав ЖК папоротников отличался достаточно высоким содержанием ННЖК (56,7-78,8\%). У представителей Polypodiopsida ненасыщенность определялась в большей степени вкладом полиненасыщенных ЖК (ПННЖК) (от 43,5 до 55,6\%), а у Ophioglossopsida - главным образом мононенасыщенных ЖК (МННЖК) (43,1\%) (табл. 3).

Таблица 3. Состав и содержание жирных кислот суммарных липидов в листьях представителей Ophioglossopsida и Polypodiopsida

\begin{tabular}{c|c|c|c|c|c|c|c|c}
\hline \multirow{2}{*}{ Кислоты } & \multicolumn{7}{|c}{ Содержание кислот, процент от суммы } \\
\cline { 2 - 9 } & I & II & III & IV & V & VI & VII & VIII \\
\hline 1 & 2 & 3 & 4 & 5 & 6 & 7 & 8 & 9 \\
\hline $16: 0$ & $16,4 \pm 0,6$ & $22,8 \pm 02,0$ & $22,8 \pm 0,1$ & $34,7 \pm 0,3$ & $30,4 \pm 0,6$ & $26,1 \pm 0,1$ & $23,1 \pm 0,5$ & $13,5 \pm 0,6$ \\
$16: 1$ & $1,2 \pm 0,3$ & $2,8 \pm 1,2$ & $1,8 \pm 0,2$ & $2,6 \pm 0,2$ & $0,6 \pm 0,0$ & $2,5 \pm 0,3$ & $2,3 \pm 0,4$ & $0,3 \pm 0,0$ \\
$18: 0$ & $1,7 \pm 0,4$ & $0,9 \pm 1,3$ & $2,0 \pm 0,4$ & $3,6 \pm 0,5$ & $3,7 \pm 0,1$ & $1,8 \pm 0,4$ & $3,2 \pm 0,1$ & $1,5 \pm 0,0$ \\
$18: 1 \mathrm{n} 9 \mathrm{t}$ & $0,5 \pm 0,1$ & $4,4 \pm 0,4$ & $4,1 \pm 1,0$ & $5,9 \pm 0,4$ & $1,6 \pm 0,0$ & $3,3 \pm 0,6$ & $4,3 \pm 0,3$ & $0,3 \pm 0,2$ \\
$18: 1 \mathrm{n} 9 \mathrm{c}$ & $38,7 \pm 2,4$ & $8,8 \pm 0,6$ & $9,1 \pm 0,0$ & $4,7 \pm 0,6$ & $10,3 \pm 0,6$ & $5,2 \pm 0,1$ & $7,7 \pm 0,2$ & $30,9 \pm 0,1$ \\
$18: 1 \mathrm{n} 7$ & $1,2 \pm 0,6$ & $2,3 \pm 0,6$ & $0,4 \pm 0,1$ & $0,3 \pm 0,1$ & - & $0,9 \pm 0,0$ & $0,5 \pm 0,4$ & - \\
$18: 2 \mathrm{n} 6 \mathrm{c}$ & $15,6 \pm 2,1$ & $14,6 \pm 1,2$ & $13,7 \pm 0,3$ & $7,7 \pm 0,5$ & $10,6 \pm 0,9$ & $8,2 \pm 0,1$ & $11,0 \pm 0,6$ & $28,9 \pm 1,5$ \\
$20: 0$ & $0,2 \pm 0,1$ & $1,2 \pm 1,0$ & $1,5 \pm 0,0$ & $1,9 \pm 0,3$ & $2,7 \pm 0,0$ & $1,8 \pm 0,5$ & $3,0 \pm 0,1$ & $1,4 \pm 0,7$ \\
$18: 3 \mathrm{n} 6$ & - & $1,6 \pm 0,0$ & $1,4 \pm 0,5$ & $0,6 \pm 0,0$ & $0,4 \pm 0,0$ & $0,6 \pm 0,7$ & $1,1 \pm 0,7$ & $0,8 \pm 0,3$ \\
$18: 3 \mathrm{n} 3$ & $13,4 \pm 0,1$ & $28,1 \pm 1,2$ & $13,4 \pm 0,4$ & $27,8 \pm 1,0$ & $25,7 \pm 0,2$ & $36,8 \pm 3,0$ & $27,5 \pm 0,1$ & $13,6 \pm 0,1$ \\
$22: 0$ & $1,2 \pm 0,2$ & $0,5 \pm 1,5$ & $1,2 \pm 0,2$ & $0,7 \pm 1,2$ & $2,6 \pm 0,1$ & $0,9 \pm 0,0$ & $3,2 \pm 0,2$ & $1,4 \pm 0,0$ \\
\hline
\end{tabular}


Окончание таблиць 3

\begin{tabular}{c|c|c|c|c|c|c|c|c}
\hline 1 & 2 & 3 & 4 & 5 & 6 & 7 & 8 & 9 \\
\hline $20: 4$ & - & $3,2 \pm 0,1$ & - & $4,6 \pm 1,3$ & $2,8 \pm 0,1$ & $3,4 \pm 0,6$ & $5,9 \pm 1,0$ & $2,4 \pm 0,1$ \\
$24: 0$ & $0,3 \pm 0,1$ & $4,0 \pm 0,2$ & $0,3 \pm 0,0$ & $1,9 \pm 2,0$ & $3,4 \pm 0,5$ & $3,9 \pm 0,4$ & $4,2 \pm 0,9$ & $1,1 \pm 0,2$ \\
$\Sigma$ Х & $6,9 \pm 0,1$ & - & $19,9 \pm 1,3$ & - & $3,4 \pm 1,6$ & - & - & $2,8 \pm 0,6$ \\
НЖК & $20,4 \pm 1,4$ & $27,2 \pm 2,1$ & $28,6 \pm 1,2$ & $42,2 \pm 2,0$ & $40,6 \pm 0,4$ & $33,0 \pm 2,6$ & $33,6 \pm 1,0$ & $18,4 \pm 0,4$ \\
ННЖК & $72,7 \pm 1,5$ & $72,8 \pm 2,1$ & $71,5 \pm 2,0$ & $57,8 \pm 2,0$ & $56,0 \pm 0,3$ & $67,2 \pm 2,1$ & $66,4 \pm 1,2$ & $78,8 \pm 0,7$ \\
МННЖК & $43,1 \pm 1,2$ & $19,8 \pm 0,2$ & $15,9 \pm 1,2$ & $14,0 \pm 1,0$ & $12,5 \pm 1,1$ & $12,7 \pm 2,0$ & $15,6 \pm 0,4$ & $31,5 \pm 1,2$ \\
ПНЖК & $29,7 \pm 3,1$ & $53,0 \pm 0,1$ & $55,6 \pm 0,6$ & $43,8 \pm 1,4$ & $43,5 \pm 1,3$ & $54,5 \pm 0,7$ & $50,8 \pm 2,0$ & $47,3 \pm 0,2$ \\
\hline
\end{tabular}

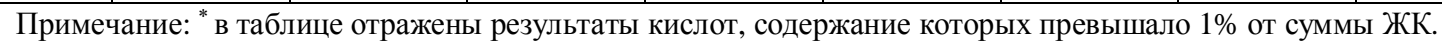

\section{Выводы}

Впервые проанализирован состав липидов и ЖК у представителей двух классов Polypodiophyta, произрастающих на Приполярном Урале в северной части национального парка «Югыд-Ва» (Республика Коми). Не выявили существенных различий по качественному составу липидов и жирных кислот шести исследованных видов папоротников от растений этой группы в целом. Однако количественные вариации изученных биохимических показателей зависели от вида и места обитания растений. Содержание СЛ варьировало от 16 до 30 мг/г сырой массы в зависимости от вида. В составе липидов растений из класcа Polypodiopsida превалировали ГЛ (58-66\% всех липидов), на долю липидов бетаинового типа приходилось от 0,1 до 1,4\%. У представителя Ophioglossopsida доминировали ФЛ (43\%), а бетаиновые липиды отсутствовали. Среди гликолипидов, участвующих в формировании хлоропластных мембран, на долю МГДГ и ДГДГ приходилось в среднем $55 \%$ и 35\% соответственно. Содержание СХДГ в листьях папоротников Polypodiopsida не превышало 20\%, а в листьях представителя Ophioglossopsida они присутствовали в следовых количествах. Основную группу ЖК составляли кислоты с длиной цепи 16-24 атомов углерода. Среди насыщенных ЖК преобладала пальмитиновая кислота, среди ненасыщенных - $\alpha$-линоленовая, олеиновая, линолевая кислоты.

Таким образом, накопление суммарных и соотношение основных групп липидов в большей степени зависели от таксономической и ботанико-географической принадлежности и не были связаны с экологической группой и ценотической приуроченностью. Количественный состав индивидуальных ГЛ и ФЛ, а также жирнокислотный состав липидов листьев папоротников видоспецифичен и может меняться в зависимости от внешних условий. Следовательно, можно полагать, что закономерности формирования липидного состава биологических мембран отражают систематическое положение и адаптацию растений к условиям обитания. Полученные данные существенно дополняют сведения о липидах высших споровых растений и расширяют представления о соответствии их метаболизма климату.

\section{Сиисок литературы}

1. Biology and Evolution of Ferns and Lycophytes. Cambridge; University Press, 2008. 468 p.

2. George L.O., Bazzaz F.A. The fern understory as an ecological filter: growth and survival of canopy-tree seedlings // Ecology. 1999. Vol. 80, N3. P. 846-856.

3. Жизнь растений. М., 1978. Т. 4. 447 с.

4. Растения. Новейшая иллюстрированная энциклопедия по зеленому царству планеты : пер. с анг. М., 2006. 512 с.

5. Mehltreter K., Walker L.R., Sharpe J.M. Fern Ecology. Cambridge; Cambridge University Press, 2010. 440 p.

6. Капранова Н.Н. Удивительные папоротники Земли. Уроки в ботаническом саду. М., 2006. 40 с.

7. Dyer A.F. The experimental Biology of Ferns. Scotland; Academic Press, 1979. 647 p.

8. Макаренко С.П., Дударева Л.В., Катышев А.И., Коненкина Т.А., Назарова А.В., Рудиковская Е.Г., Соколова Н.А., Черникова В.В., Константинов Ю.М. Влияние низких температур на жирнокислотный состав контрастных по холодоустойчивости видов злаков // Биологические мембраны. 2010. Т. 27, № 6. С. 482-488.

9. Смирнов Л.П., Богдан В.В. Липиды в физиолого-биохимических адаптациях эктотермных организмов к абиотическим и биотическим факторам среды. М., 2007. 182 с.

10. Розенцвет О.А., Филин В.Р., Саксонов С.В., Мещеряков В.В. Сезонная динамика полярных липидов в листьях папоротников Dryopteris filix-mas и Mattteuccia struthiopteris // Биохимия. 2002. Т. 67, № 9. С. 1215-1221.

11. Розенцвет О.А., Богданова Е.С., Козлов В.Г., Саксонов С.В., Ужамецкая Е.А., Юнина В.П., Сидоренко М.В. Сезонная изменчивость мембранных фосфо- и бетаиновых липидов Pteridium aquilinum в зависимости от условий обитания // Известия Самарского НЦ РАН. 2004. Т. 6, № 2. С. 299-305.

12. Rozenstvet O.A. Comparative examination of distribution of phospholipids and betaine lipid DGTS in tropical fern species // Biochemical Systematic and Ecology. 2004. Vol. 32. Pp. 303-311.

13. Розенцвет О.А., Богданова Е.С., Табаленкова Г.Н., Головко Т.К., Захожий И.Г. Эколого-биохимические свойства представителей высших споровых растений Южного Тимана // Поволжский экологический журнал. 2011. №4. C. 489-499. 
14. Головко Т.К., Табаленкова Г.Н., Дымова О.В. Пигментный комплекс растений Приполярного Урала // Ботанический журнал. 2007. Т. 92, № 11. С. 1732-1741.

15. Головко Т.Г., Далькэ И.В., Табаленкова Г.Н., Гармаш Е.В. Дыхание растений Приполярного Урала // Ботанический журнал. 2009. Т. 94, № 8. С. 1216-1226.

16. Дегтева С.В., Мартыненко В.А. Растительность и флора природного парка «Югыд-ва» (Республика Коми) // Ботанический журнал. 2000. Т. 85, №11. С. 76-86.

17. Мартыненко В.А., Дегтева С.В. Конспект флоры национального парка «Югыд-Ва» (Республика Коми). Екатеринбург, 2003. 108 с.

18. Кеммерих А. О. Приполярный Урал. М., 1970. 155 с.

19. Bligh E.G., Dyer W.J.A rapid method of lipid extraction and purification // Canad. J. Biochem. Physiol. 1959. Vol. 37. Pp. 911-917.

20. Кейтс М. Техника липидологии. М., 1975. 323 с.

21. Vaskovsky V.E., Latyshev N.A. Modified Jungnickel s reagent for detecting phospholipids and other phosphorus compounds on thin-layer chromatograms // J. Chromatogr. 1975. Vol. 115, N1. Pp. 246-249.

22. Rozentsvet O.A., Saksonov S.V., Dembitsky V.M. Occurence of diacylglyceryl-trimethylhomoserines and major phospholipids in some plants // Phytochemistry. 2000. Vol. 53. Pp. 1-7.

23. Черепанов С.К. Сосудистые растения России и сопредельных государств. СПб., 1995. 990 с.

24. Somerville Ch., Browse J., Jaworski J.G., Ohlrogge J.B. Lipids. In Biochemistry and Molecular Biology of Plants. USA; Rockville, 2000. Рp. 456-527.

25. Юровицкий Ю.Г., Сидоров В.С. Эколого-биохимический мониторинг и эколого-биохимическое тестирование в районах экологического неблагополучия // Известия РАН. Сер. биол. 1993. №1. С. 74-82.

26. Dörman P., Benning C. Galactolipids Rule in Seeds Plant// Trends in Plant Science. 2002. Vol. 7. Pp. 112-118.

27. Lee A.G. How Lipids Affect the Activities of Integral Membrane Proteins // Biochim. Biophys. Acta. 2004. Vol. 166. Pp. 62-87.

28. Hölzl G., Dörman P. Structure and function of glycerolipids in plants and bacteria // Prog. Lipid Res. 2007. Vol. 46. Pp. 225-243.

29. Lipids in Photosynthesis. Essential and Regulatory Functions. Netherlands; Springer, 2009. 473 pp.

30. Алаудинова Е.В., Миронов П.В., Репях С.М. Жирные кислоты мембранных липидов живых тканей почек лиственницы сибирской // Химия растительного сырья. 2000. №2. С. 41-45.

31. Мокроносов А.Т., Гавриленко В.Ф. Фотосинтез. Физиолого-экологические и биохимические аспекты. М., 1992. $320 \mathrm{c}$.

32. Граскова И.А., Дудаева Л.В., Живетьев М.А., Стольбикова А.В., Соколова Н.А., Войников В.К. Динамика сезонных изменений жирнокислотного состава, степени ненасыщенности жирных кислот и активности ациллипидных десатураз в тканях некоторых лекарственных растений, произрастающих в условиях Предбайкалья // Химия растительного сырья. 2011. №4. С. 223-230.

33. Лось Д.А. Структура, регуляция экспрессии и функционирование десатураз жирных кислот // Успехи биологической химии. 2001. Т. 41. С. 163-198.

34. Murata N., Los A.D. Membrane Fluidity and Temperature Perception // Plant Physiol. 1997. Vol. 115, N3. Pp. 875-879.

Поступило в редакиию 3 октября 2012 2.

Rozentsvet O.A. ${ }^{*}{ }^{*}$, Bogdanova E.S. ${ }^{1}$, Golovko T.K. ${ }^{2}$, Zakhozhiy I.G. ${ }^{2}$ COMPOSITION OF LIPIDS OF THE LEAVES OF SOME REPRESENTATIVES OF POLYPODIOPHYTA IN THE POLAR URALS

${ }^{1}$ Institute of Ecology of the Volga River Basin, Russian Academy of Sciences, Komzina st., 10, Togliatti, 445003

(Russia),e-mail: cornales@mail.ru

${ }^{2}$ Institute of Biology, Komi Scientific Center, Ural Branch of the Russian Academy of Sciences, Kommunisticheskaia st., 28, Syktyvkar, 167982 (Russia)

The composition of lipids and fatty acids of 6 leaves species - the representatives of two classes of Rolypodiophyta growing in the Polar Urals was studied. Glycolipids prevailed at the plants of Polypodiopsida (58-66\% of lipids), 0,1-1,4\%. Fell to the share of betaine lipids. Phospholipids prevailed at the representative of Ophioglossopsida (43\%), and betaine lipids were absent. The main group of saturated fatty acids had the acids with chain length of 16-24 carbon atoms. It was established that the contents and ratio of the main groups of lipids to a considerable degree depended on taxonomic and botanic-natural region, but were poorly related to ecological group and ecosystems.

Keywords: fatty acids, reserve lipids, membrane lipids, Ophioglossopsida, Polypodiopsida.

\footnotetext{
* Corresponding author.
} 


\section{References}

1. Biology and Evolution of Ferns and Lycophytes. Cambridge; University Press, 2008. 468 p.

2. George L.O., Bazzaz F.A. Ecology, 1999, vol. 80, no. 3, pp. 846-856.

3. Zhizn' rastenii. [Plant Life]. Moscow, 1978, vol. 4, 447 p. (in Russ.).

4. Rasteniia. Noveishaia illiustrirovannaia entsiklopediia po zelenomu tsarstvu planety. [The latest illustrated encyclopedia on green planet kingdom.]. Moscow, 2006, 512 p. (in Russ.).

5. Mehltreter K., Walker L.R., Sharpe J.M. Fern Ecology. Cambridge; Cambridge University Press, 2010. 440 p.

6. Kapranova N.N. Udivitel'nye paporotniki Zemli. Uroki v botanicheskom sadu. [Amazing Earth ferns. Lessons in a botanical garden.]. Moscow, 2006, 40 p. (in Russ.).

7. Dyer A.F. The experimental Biology of Ferns. Scotland; Academic Press, 1979. 647 p.

8. Makarenko S.P., Dudareva L.V., Katyshev A.I., Konenkina T.A., Nazarova A.V., Rudikovskaia E.G., Sokolo-va N.A., Chernikova V.V., Konstantinov Iu.M. Biologicheskie membrany, 2010, vol. 27, no. 6, pp. 482-488. (in Russ.).

9. Smirnov L.P., Bogdan V.V. Lipidy $v$ fiziologo-biokhimicheskikh adaptatsiiakh ektotermnykh organizmov $k$ abioticheskim i bioticheskim faktoram sredy. [Lipids in the physiological and biochemical adaptations ectothermic organisms to abiotic and biotic environmental factors.]. Moscow, 2007, 182 p. (in Russ.).

10. Rozentsvet O.A., Filin V.R., Saksonov S.V., Meshcheriakov V.V. Biokhimiia, 2002, vol. 67, no. 9, pp. $1215-1221$. (in Russ.).

11. Rozentsvet O.A., Bogdanova E.S., Kozlov V.G., Saksonov S.V., Uzhametskaia E.A., Iunina V.P., Sidorenko M.V. Izvestiia Samarskogo NTs RAN, 2004, vol. 6, no. 2, pp. 299-305. (in Russ.).

12. Rozenstvet O.A. Biochemical Systematic and Ecology, 2004, vol. 32, pp. 303-311.

13. Rozentsvet O.A., Bogdanova E.S., Tabalenkova G.N., Golovko T.K., Zakhozhii I.G. Povolzhskii ekologicheskii zhurnal, 2011, no. 4, pp. 489-499. (in Russ.).

14. Golovko T.K., Tabalenkova G.N., Dymova O.V. Botanicheskii zhurnal, 2007, vol. 92, no. 11, pp. 1732-1741. (in Russ.).

15. Golovko T.G., Dal'ke I.V., Tabalenkova G.N., Garmash E.V. Botanicheskii zhurnal, 2009, vol. 94, no. 8, pp. $1216-1226$. (in Russ.).

16. Degteva S.V., Martynenko V.A. Botanicheskii zhurnal, 2000, vol. 85, no. 11, pp. 76-86. (in Russ.).

17. Martynenko V.A., Degteva S.V. Konspekt flory natsional'nogo parka «Iugyd-Va» (Respublika Komi). [Synopsis of the flora of the national park "Yugyd Va" (Komi Republic)]. Ekaterinburg, 2003, 108 p. (in Russ.).

18. Kemmerikh A.O. Pripoliarnyi Ural. [Ural Mountains]. Moscow, 1970, 155 p. (in Russ.).

19. Bligh E.G., Dyer W.J. Canad. J. Biochem. Physiol., 1959, vol. 37, pp. 911-917.

20. Keits M. Tekhnika lipidologii. [Tech lipidology]. Moscow, 1975, 323 p. (in Russ.).

21. Vaskovsky V.E., Latyshev N.A. J. Chromatogr., 1975, vol. 115, no. 1, pp. 246-249.

22. Rozentsvet O.A., Saksonov S.V., Dembitsky V.M. Phytochemistry, 2000, vol. 53, pp. 1-7.

23. Cherepanov S.K. Sosudistye rasteniia Rossii i sopredel'nykh gosudarstv. [Vascular plants of Russia and adjacent states]. St. Petersburg, 1995, 990 p. (in Russ.).

24. Somerville Ch., Browse J., Jaworski J.G., Ohlrogge J.B. Lipids. In Biochemistry and Molecular Biology of Plants. USA; Rockville, 2000. Pp. 456-527.

25. Iurovitskii Iu.G., Sidorov V.S. Izvestiia RAN. Seriia biologicheskaia, 1993, no. 1, pp. 74-82. (in Russ.).

26. Dörman P., Benning C. Trends in Plant Science, 2002, vol. 7, pp. 112-118.

27. Lee A.G. Biochim. Biophys. Acta, 2004, vol. 166, pp. 62-87.

28. Hölzl G., Dörman P. Prog. Lipid Res., 2007, vol. 46, pp. 225-243.

29. Lipids in Photosynthesis. Essential and Regulatory Functions. Netherlands; Springer, 2009. 473 pp.

30. Alaudinova E.V., Mironov P.V., Repiakh S.M. Khimiia rastitel'nogo syr'ia, 2000, no. 2, pp. 41-45.

31. Мокроносов А.Т., Гавриленко В.Ф. Фотосинтез. Физиолого-экологические и биохимические аспекты. [Photosynthesis. Physiological-environmental and biochemical aspects]. Moscow, 1992, 320 p. (in Russ.).

32. Graskova I.A., Dudaeva L.V., Zhivet'ev M.A., Stol'bikova A.V., Sokolova N.A., Voinikov V.K. Khimiia rastitel'nogo syria, 2011, no. 4, pp. 223-230. (in Russ.).

33. Los' D.A. Uspekhi biologicheskoi khimii, 2001, vol. 41, pp. 163-198. (in Russ.).

34. Murata N., Los A.D. Plant Physiol., 1997, vol. 115, no. 3, pp. 875-879. 